\title{
Taxonomy and Phylogeny in African water mites of the genus Diplodontus Dugés, 1834 (Acari, Hydrachnidia, Hydryphantidae)
}

\author{
R. Gerecke
}

Biesingerstr. 11, D 72070 Tübingen, Germany. E-mail : reinhard.gerecke@uni-tuebingen.de

\begin{abstract}
The diagnostic features of the African species of the monotypic subfamily Diplodontinae K. Viets, 1936 are discussed. $D$. chutteri K.O.Viets, 1980 obviously represents the outgroup of all remaining species. D. scapularis Dugés, 1834 and $D$. semiperforatus Walter, 1925, both in Africa restricted to the palaearctic part, are sister species characterized by synapomorphic character states in the genital field and shape of palps and legs. Diplodontus schaubi gracilirostris Lundblad, 1942 is elevated to species rank. Two species from Madagascar are described as new to science, with morphological characteristics and a habitat preference so far unknown in this genus. Obviously, they have evolved particular adaptations under long term stable conditions in isolated rain forests of $\mathrm{N}$ and E Madagascar. A new diagnosis is proposed for the subfamily Diplodontinae K.Viets, 1936.
\end{abstract}

Keywords : Diversity, zoogeography, Madagascar, inland waters, sexual dimorphism.

\section{Introduction}

Representatives of the water mite genus Diplodontus are known from scattered localities in temperate and tropical areas in Europe, Asia, Africa and Australia (K.O. Viets, 1980; Jin 1995). All species previously described inhabit small, mostly stagnant, water bodies. In the Southwestern palaearctic species D. semiperforatus Walter, 1925, a particular tolerance against (or preference for ?) high electrolyte concentrations is observed (Gerecke 1991). Larvae of this species and of D. scapularis Dugés, 1834 were found parasitic on aquatic beetles (Moreno Alcaraz et al. submitted.).During recent field work in Madagascar, two additional species of the genus have been detected that contribute important new aspects concerning the diversity of Diplodontine mites. The aim of this paper is to revise, and to add new records of, the species so far recorded from Africa, to describe the new species from Madagascar, and to discuss their morphological features on a biogeographical and taxonomical background.

\section{Material and Methods}

During the author's field work in Madagascar, mites were collected by hand netting spring and running water habitats, and picked out on the spot from a white pan. Later, the whole material from this expedition was sorted on subfamily or genus level (Goldschmidt \& Gerecke 2003). Previously unstudied mites from the collections in the Muséum National d'Histoire Naturelle Paris (conservated in ethanol) and from our own collection (conservated in Koenike's fluid) were dissected and slide mounted, partially in glycerine jelly, partially in Hoyer's fluid. The following abbreviations are used: NMHU = Naturhistorisches Museum der Humboldt-Universität Berlin; MNHN = Muséum National d'Histoire Naturelle Paris; SMF = Senckenberg Museum Frankfurt. For explanation of further abbreviations see Gerecke (1996). All measurement data $(\mu \mathrm{m})$ are composed in the Tables 1 and 2.

For this investigation, the following material has been examined (individual numbers given as males / females / deutonymphs): 


\section{Diplodontus scapularis (Dugés, 1835):}

Italy (Gerecke 1991, in coll. Gerecke, Tübingen), Basilicata: I 441 (Potenza). Pollino, Rotonda; fiume Mercure near Ponte Mercure, 320m, WE 87 25, 07.08.1986 (1/1/2); Sicily: I 82 (Palermo). Torrente Belici at bridge near railway station Marianopoli, 330m, VB 02 64, 27.06 .1985 (1/0/0); I 299 (Palermo). Corleone, Torrente Batticano in Contrada Torrazza, 270m, UB 425 869, 02.04.1986 (0/1/0); I 465 (Agrigento). Ribera, Calamonaci, fiume Verdura near Cozzo Tragaleggi, 95m, UB 47 56, 22.08.1986 (0/1/1); I 478 (Trapani). Castelvetrano, Fiume Grande in Contrada Pozzillo, 90m, UB 02 80, 05.09.1986 (0/1/0); I 483 (Trapani). Marsala. Pozzillo, fountain Timpone Pozzillo, 60m, TB 892 923, 07.09.1986 (0/2/5); I 485 (Trapani) Fiume Bordino catchment, Fiume di Fittasi at Ponte Fittasi, 95m, TB 95 99, 07.09.1986 (0/1/0).

Morocco (new records, leg. Ribera et al., in coll. Gerecke, Tübingen), MAR 18 Oued Guir near Toulal, 32 ${ }^{\circ} 16^{\prime} 26 \mathrm{~N}, 3^{\circ} 59^{\prime} 25 \mathrm{~W}, 1175 \mathrm{~m}, 16.07 .1997$, (1/1/0); MAR 22 Near Bachkoun, 3041'79N, 7¹6'17W, 1400m, 18.07.1997 (1/2/1); MAR 23 Near Asfazimer, $30^{\circ} 37^{\prime} 48 \mathrm{~N}, 7^{\circ} 50$ '03W, 1700m, 19.07.1997 (0/1/0); MAR 27 Oued Âït-Baha near Tioulit, 2952'59N, 900’65W, 1150m, 21.07.1997 (1/2/0).

\section{Diplodontus schaubi (Koenike, 1893):}

Type series: Tansania NMHU 316 Quilimane, Sumpf Litololi-Kululi, Dr. Stuhlmann leg. 10.1 .1889 (1/0/0): only one palpus; the rest of the specimen lost; from Koenike's catalogue (in NMHU) results that he prepared two males, two females and one deutonymph, but included only one female (317) and one male palp (316) into his slide collection; both specimens designated as types; as prep. 317 obviously contains a complete specimen, this preparation would be the candidate for lectotype designation - however, it could not be found in the collection; a further specimen designated as «Type» (NMHU 1229, male, Madagascar) was published after the description and is not a part of the type series.

Madagascar (Gerecke in press and one new record): MNHN B 10 i, NW, bas Sambirano massaban A 09/1945 J.Millot (1/0/1); MNHN B 15 i, N, Sambirano (marais A), no collection date, J.Millot (0/1/1); MNHN E 14 M Marais Marovoay près Majunga, no collection date, Waterlot (0/2/0). MNHN MD 149b Maroambihy (Sambava, Antsiranana), left affl. R.Lokoho upstr. from the village, $90 \mathrm{~m}$, pool. Gerecke \& Goldschmidt 12.11.2001 (0/0/1).
Tansania (K.Viets 1911, from vial collection K.Viets, in coll. Gerecke, Tübingen): D.O.Afrika, Nyembe-Bulungwa 22.08.1910 coll. Hammerstein (4/0/0).

Zaire (K.O.Viets 1973): SMF4623, 4624, Kivu-See, W-Ufer, Böttger leg. 27.2.1972 Sign.1 (0/2/0); SMF 4847 Kivu-See, W-Ufer, Statzner leg. 31.7.1972 Sign. II $(1 / 0 / 0)$.

South Africa (K.O.Viets 1964): SMF K.O.Viets 2160, Klein Vaal River near source, Süd Africa Val 848; Chutter leg. 11.11.1959 (0/1/0).

\section{Diplodontus opimus (Koenike, 1896):}

Type series: Madagascar, lectotype male, here designated: NMHU 1226, Mojanga (Majunga) Dr. Voeltzkow coll. («Type») (male, partly dissected but with gnathosoma and chelicerae in situ); paralectotypes: NMHU 1225 like 1226 (two specimens, only mouthparts); NMHU 1222 Madagascar Mojanga NMHU (0/1/0) (idiosoma without mouthparts); NMHU 1223 (number no more decipherable, deduced from the catalogue), like 1226 (genital field and mouthparts of a male, one additional palp); NMHU 1224 (following the catalogue, no number on the slide), Amparangidro, Reissee, Dr. Voeltzkow ges. Frühj. 1892 (two specimens, one lacking the whole gnathosoma including appendages, the other one chelicera and one palp).

In his catalogue, Koenike designated alltogether six preparations as «Types», but later he cancelled these designations in all but number 1225, while in his collection slide number 1222 is marked in red colour. Slide 1225 contains mouthparts of at least two specimens (one squeezed gnathosomal base, three palps and two pairs of chelicerae) and therefore cannot be referred to a definitive holotype. The fact that this slide contains exactly those mouthparts lacking in the specimens mounted on slide 1224 suggests, that there might have happened confusion between different collecting sites. In view of such contradictions, I decided to designate slide 1226 as a lectotype.

Diplodontus silvestrii (Daday, 1898): India: Delhi, Panesar coll., unpubl. (1/0/0). Diplodontus semiperforatus (Walter, 1925):

Italy: (Gerecke 1991, in coll. Gerecke, Tübingen). Sicily: I 84, I 571 (Caltanissetta) Torrente Salito near Stazione Mimiani, 285 m, VB 086 564, 27.06.1985 (8/3/3), 14.09.1987 (7/2/1); I 200 (Caltanissetta) Bompensiere, Fiume Belici upstr. confluence Fiume Salito, 200 m, UB 966 539, 08.10.1985 (0/0/1); I 201 Sicilia (CL) (Caltanissetta) Bompensiere, Fiume Salito upstr. confluence Fiume Belici, 200 m, UB 969 539, 
08.10.1985 (0/0/1); I 815 (Trapani) Pantelleria, Specchio di Venere, 2 m, QF 66 78, 11.04.1983 (4/9/3).

Morocco (new records, leg. Remy): MNHN 2 gamma 33, Oued Bour 172 29.08.1953 (2/2/0); MNHN 2 gamma 20, Oued Gheris, barrage de Mcharza (Rissani) 26.08.1953 (0/1/0).

\section{Diplodontus gracilirostris (Lundblad, 1942):}

Type series: Kenya, holotype female SMNH 3153, Kenya Colony, Ithanga Hills, Mt. Kenya. Juni 1931. H. Gravnik (Preparation in bad conditions due to oblique position of mouthparts and precipitations in the mounting medium; as a consequence, $\mathrm{L} / \mathrm{H}$ measurements of palps and legs impossible).

\section{Diplodontus mandibulatus Lundblad, 1947:}

Type series: West Australia, Holotype female SMNH 3457, Claremont, Butler's swamp. 20.01.1937 (F. Linder); paratype female, SMNH 3425, like holotype.

\section{Diplodontus haliki Lundblad, 1947:}

Type series: West Australia, Holotype male SMNH 3421; paratype female SMNH 3422.

Further material examined: Australia (K.O.Viets 1980): SMF K.O.Viets 6445, 6446 Nortwestern NSW. Roadside pond near Boggarón, Timms leg. 14.1.1977 $(1 / 1 / 0)$

\section{Diplodontus chutteri K.O.Viets, 1981:}

Type series: South Africa: Holotype, SMF 6502: Vaal River where crossed by the road from Standenton to Telliers (VAL 11764) Chutter leg. 8.6.1960 (0/1/0); paratype, SMF 6508: ditto (VAL 7111) 18.8.1959 $(0 / 1 / 0)$.

\section{Results}

\section{Diplodontus scapularis (Dugés, 1835)}

Description: Both sexes: Integument smooth or (in old specimens) with small sclerite dots marking the dorsal muscle attachments; medial margins of $\mathrm{Cx}-1+2$ with subcutaneous extensions directed perpendicularly to the idiosoma main axis, but leaving a small membraneous space at the posterior margin of the gnathosomal bay; legs stout, bearing long, fine swimming hairs (numbers in parentheses) on segments II-L-5 (1112), III-L-4 (10), III-L-5 (15-18), IV-L-3 (1-2), IV-L-4 (12-13), IV-L-5 (16-20); genital plates halfmoon-shaped, laterally equally rounded with reinforced posteriomedial angles; maximum $\mathrm{W}$ in the posterior third; a relatively high number of setae (50-75) lined up at the medial margins, and accumulated near the posteromedial angles, of the genital plates; gnathosoma with very stout palps (L/H P-2 1.0-1.2, P-4 2.7-2.8), P-2 with one or two prominent ventrodistal setae; chelicera with rather short claw (basal segment/claw ratio 1.7-2.0).

Male: IV-L more robust than in females (e.g. IV-L-5 L/H 3.6) and with thickened, short claws; genital field minor in extensions, with about 50 medial setae; mediocaudal angles of genital plates distinctly projecting, with a dense setae cover; genital sceleton reduced in size $(\mathrm{L} 150 \mu \mathrm{m})$, brachia distalia larger than brachia proximalia.

Female: IV-L more slender (e.g. IV-L-5 L/H 4.15.6), claws not differing as compared with those of IIII-L; genital field major in extensions, with about 75 medial setae, mediocaudal angles of genital plates more strongly sclerotized, but less projecting than in males and less densely setated.

Deutonymph: generally minor in dimensions and with lower seta numbers, but similar in cheliceral proportions, and distribution and number of swimming hairs.

Habitat: Standing waters and pools of lowland running waters.

Discussion: The type series of $D$. scapularis is lost. However, on the base of the figure of the chelicera in the original description, populations with a short cheliceral claw can be attributed to this species and distinguished from $D$. semiperforatus, the only further taxon of the genus known in the Southern palaearctic region (Gerecke 1991).

Distribution: Circummediterranean, two old records from N France and N Germany (see Gerecke 1991).

\section{Diplodontus schaubi (Koenike, 1893)}

Figs 1; 2 A, B; 3 A

Description: Both sexes: Integument without sclerotized muscle insertions; medial subcutaneous extensions of $\mathrm{CX}-1 / 2$ (Fig. $1 \mathrm{~A}$ ) in their distal parts bent caudally; legs rather slender, bearing long, fine swimming hairs (as depicted in Fig. 2 A for the IV-L, numbers in parentheses) on segments II-L-5 (7-10), III-L-4 (5-12), III-L-5 (11-18), IV-L-3 (1-3), IV-L-4 (6-18), IV-L-5 (10-18); genital field (Fig. $1 \mathrm{~A}$ ) with triangular acetabula-bearing plates, their lateral margins nearly straight in their anterior parts and here often with a narrow, acetabula-free edge, maximum $\mathrm{W}$ at posterior edge; medial setae on genital plates regularly arranged along the margin, a few longer setae concentrated near the posteromedial edge; gnathosoma with stout palps (Figs 2 B, 


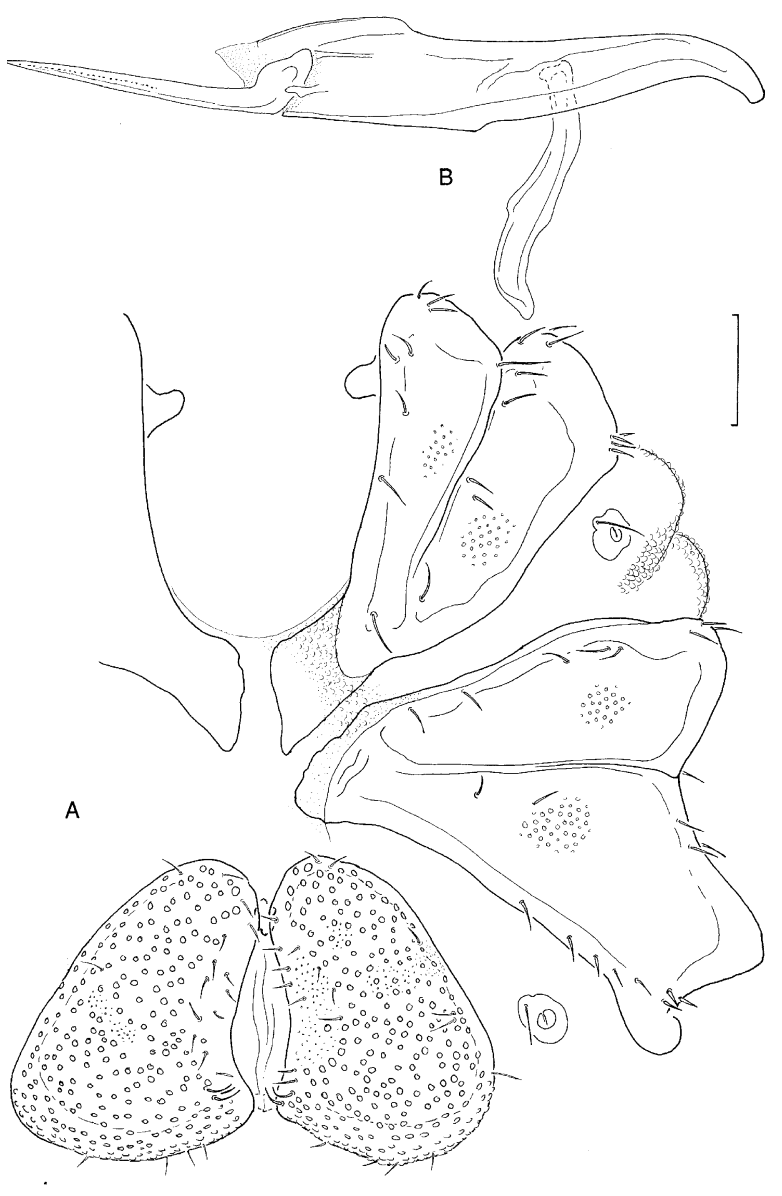

Fig. 1. Diplodontus schaubi from Madagascar. A male (MNHN B 10 i), left coxal area and genital field. B female (MNHN B 15 i), chelicera. Bar $=100 \mu \mathrm{m}$.

3 A, L/H P-2 1.2-1.4, P-4 2.9-3.3), three to five prominent medial setae at the distal margin of P-2; chelicera (Fig. 1 B) L ratio basal segment/claw 1.63-1.86.

Male: about 25 genital setae flanking the gonopore; genital sceleton not reduced in dimensions (L 200-270 $\mu \mathrm{m})$, with brachia proximalia distinctly more extending than brachia distalia; legs more stout than in female (L/H IV-L-3 2.67, IV-L-4 4.00, IV-L-5 4.71), but no sexual dimorphism in claw shape.

Female: 40-62 genital setae flanking the gonopore; legs more slender than in male (L/H IV-L-3 > 3.0, IVL-4 > 4.5, IV-L-5 > 5.0).

Deutonymph: generally minor in dimensions and with lower numbers of setae, but similar in chelicera proportions, and distribution and number of swimming hairs.
Habitat: Standing waters and pools of lowland running waters

Discussion: $D$. schaubi differs from both $D$. scapularis and D. semiperforatus, the two species known from North Africa, in the genital plates triangular in shape and without distinct, densely setated, mediocaudal extensions; a larger male genital sceleton; lower numbers of swimming hairs; and the presence of three or more long mediodistal setae on P-2. In the relatively long cheliceral claw it is similar to D. semiperforatus. From this species it differs furthermore in minor dimensions of the genital field, the male genital sceleton with brachia distalia more extending than brachia proximalia, and more stout palp segments P-3 and P-4.

The diagnostic differences separating $D$. silvestrii (Daday, 1898) - recorded from Ceylon, India and China - from $D$. schaubi have never been discussed. A comparison of measurements given by Cook (1967) and from a single specimen from India (Table 1) reveal that both species are very similar in dimensions and leg setation. Furthermore, also in $D$. silvestrii the genital plates are triangular in shape. At present state of knowledge, $D$. silvestrii differs in a shorter cheliceral claw (L ratio basal segment/claw in males $>1.9$, D. schaubi < 1.9). From this point of view, D. assilvesteii Jin, 1995 from China agrees with $D$. silvestrii, while the chelicera of a second species recently described from China, D. wandingensis Jin, 1995 is similar in shape to that of $D$. schaubi (basal segment/claw ratio about 1.7).

Also D. haliki Lundblad, 1947 from Australia is similar to $D$. schaubi in most dimensions. This species differs from both $D$. schaubi and $D$. silvestrii in the more slender P-4 (L/H 3.4-3.5, in the compared species 2.9-3.3).

A further species described from Australia, D. mandibulatus Lundblad, 1947, found sympatric with D. haliki, but also recorded from Tasmania, is similar to $D$. haliki in the slender palp segment $\mathrm{P}-4$, but differs from all three compared species in the by far larger cheliceral claw (basal segment/claw ratio 1.3-1.5).

D. schaubi and the species discussed here are similar mostly in plesiomorphic character states such as presence and number of swimming hairs, dimensions and formation of the genital sceleton, and the absence of a particular sexual dimorphism in the shape of legs and genital field. More material should be studied in order to get insight in the stability of measurement values and relations, and the presence of possible further diagnostic differences. In particular, diagnostic features and taxonomic relationships of the Asian species re- 
quire further revision. One female from South Africa (SMF 2160), attributed by K.O.Viets to D. schaubi, possibly represents a still undescribed species differing from the remaining specimens in a more slender genital field (L/W 0.77) bearing a lower number of acetabula (200), lower numbers of genital (20) and swimming setae, and a more slender palp.

Habitat: Standing waters; the only specimen collected in a river (MD 149b) taken from a pool with luxuriant macrophyte vegetation.

Distribution: South and East Africa, North and West Madagascar.

\section{Diplodontus opimus (Koenike, 1898)}

Figs 2 C; 3 B, E

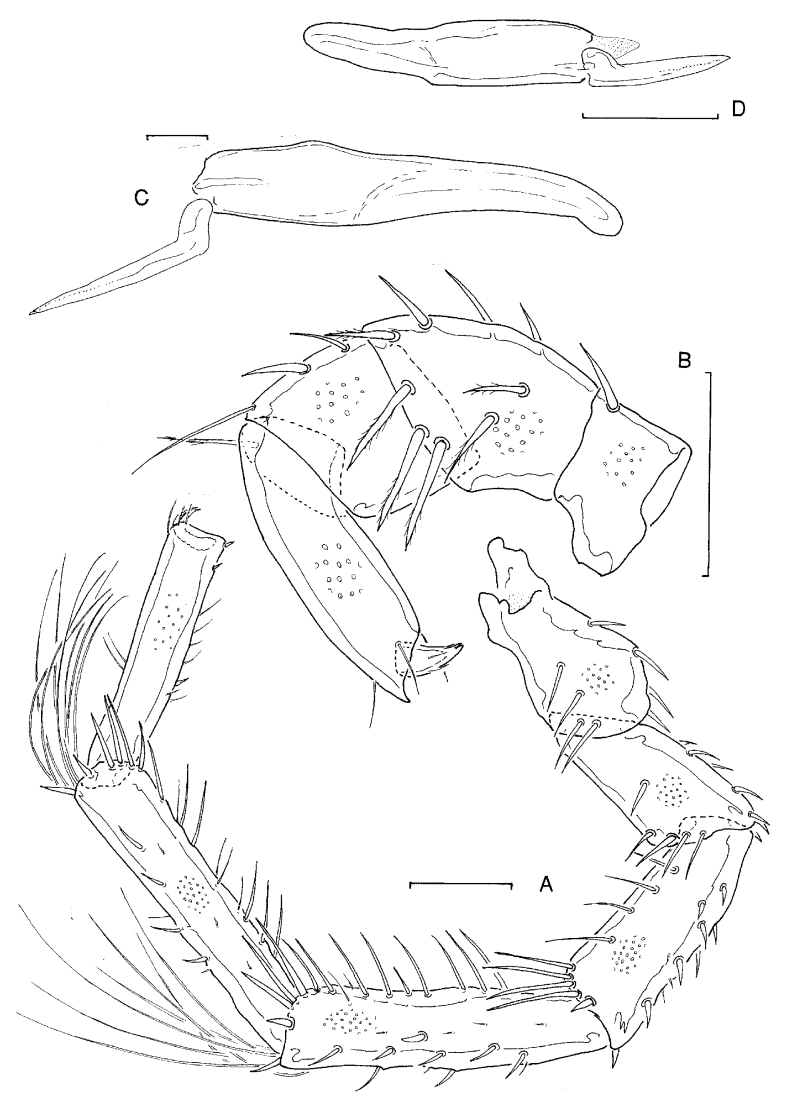

Fig. 2. A, B. Diplodontus schaubi from Madagascar, male (MNHN B 10 i). A IV-L; B palpus, medial view; C Diplodontus opimus, paralectotype female, chelicera; D Diplodontus chutteri, holotypus female, chelicera $\mathrm{Bar}=100 \mu \mathrm{m}$.
Description: Both sexes: Idiosoma and gnathosoma very large: idiosoma total $\mathrm{L}$ up to $4.000 \mu \mathrm{m}$ (original description), measurements from the type series: L/W Cx-1+2 400-460/650-720, Cx-3+4 800-870/780-860, genital field 400/590-650, total L chelicera 900-940, palp 650-780 $\mu \mathrm{m})$; integument without sclerotized muscle insertions; medial subcutaneous extensions of Cx-1/2 bent caudally in their distal parts; legs rather slender, bearing long, fine swimming hairs (numbers in parentheses) on segments II-L-5 (7-11), III-L-4 (2227), III-L-5 (13-35), IV-L-3 (0-2), IV-L-4 (22-35), IVL-5 (29-40); no sexual dimorphism in shape of IV-L segments and claws; genital field (Fig. 3 E) with equally rounded acetabula-bearing plates, maximum $\mathrm{W}$ in the centre; setae on genital plates in rather low numbers (40-50) and short, a group of such hairs arranged in the posteromedial area of the plates, but no extensions of the plates in this area; gnathosoma with slender palps (Fig. $3 \mathrm{~B}, \mathrm{~L} / \mathrm{H} \mathrm{P}-4>4.0$, L ratio $\mathrm{P}-2 / \mathrm{P}-4$ about 0.6$), \mathrm{P}-2$ bearing three to five prominent medial setae at the distal margin; chelicera (Fig. 2 C) with short claws (basal segment/claw ratio 2.00-2.13, calculated from the figure in the original description 1.93).

Male: genital sceleton very large (L $350 \mu \mathrm{m}$ ), with brachia proximalia distinctly more extending than brachia distalia.

Habitat: Known from a rice field lake and one not further described site, collected in springtime.

Discussion: Koenike considered the presence of five strong medial setae on P-2 and the shape of the subcutaneous medial projections of $\mathrm{Cx}-1+2$ (with their tips bent caudally) as important diagnostic features of this species. However, Lundblad (1947) underlined the individual variability in the number of medial setae, and CX-1+2 are found similar to D. opimus in most specimens of $D$. schaubi (see above). D. opimus has never been discussed again since the first description and appeared a doubtful species as it was recorded coexisting with D. schaubi. Our data (Table 1) reveal that D. opimus differs from all other species of the genus in distinctly major dimensions and higher swimming hair numbers. As in the studied material many swimming hairs are probably lost or not detected due to the darkened mounting medium, the latter character will result yet more distinct when fresh material is studied. $D$. opimus can be distinguished from $D$. schaubi also in the presence of round, not triangular genital plates, and from all species known at that time, in the rather slender $\mathrm{P}-4$ with $\mathrm{L} / \mathrm{H}$ ratio $>4.0$. In contrast to the statement of Koenike (who attributed to D. scapularis a long cheliceral claw, probably confusing this species with $D$. semiperforatus, not yet known a the time), 
D. opimus is similar to D. scapularis with regard to the relatively short cheliceral claw. Apart from differences in dimensions, presence or absence of sexual dimorphism, and shape and setation of palp segments, these two species can be separated in the male sex on the base of the genital sceleton (in D. scapularis with brachia distalia more extended than brachia proximalia).

Distribution: West Madagascar (Amparangidro, Majunga) - only known from the loci typici.

\section{Diplodontus semiperforatus (Walter, 1925)}

Description: Both sexes: Integument smooth or (in old specimens) with small sclerite dots marking the dorsal muscle attachments; medial margins of $\mathrm{Cx}-1+2$ with subcutaneous extensions directed perpendicularly to the idiosoma main axis; legs stout, bearing long, fine swimming hairs (numbers in parentheses) on segments II-L-5 (10-11), III-L-4 (8-11), III-L-5 (15-16), IV-L-3 (1), IV-L-4 (12-15), IV-L-5 (15-22); acetabulabearing plates halfmoon-shaped, laterally equally rounded with reinforced posteriomedial angles; maximum $\mathrm{W}$ in the posterior third; a relatively high number of setae (60-90) lined up at the medial margins, and accumulated near the posteromedial angles, of the genital plates; gnathosoma with very stout palps (L/H P-2 0.9-1.3, P-4 2.1-3.0), P-2 with one or two prominent ventrodistal setae; cheliceral claw long and slender (basal segment/claw ratio 1.3-1.7)

Male: IV-L more robust than in females (e.g. IV-L-5 L/H 3.1-3.8) and with thickened, short claws; genital field minor in dimensions, with about 60 medial setae; mediocaudal angles of genital plates distinctly projecting, with a dense setae cover; genital sceleton reduced in size $(\mathrm{L} 130 \mu \mathrm{m})$, brachia distalia minor than brachia proximalia.

Female: IV-L more slender (e.g. IV-L-5 L/H 4.75.6), claws not differing as compared with those of IIII-L; genital field major in dimensions, with about 90 medial setae, mediocaudal angles of genital plates more strongly sclerotized, but less projecting than in males and less densely setated.

Deutonymph: Generally minor in dimensions and setae numbers, but similar in chelicera proportions, and distribution and number of swimming hairs.

Habitat: Brackish and hypersaline inland waters (Gerecke 1991).

Discussion: Both the stout shape of the palp, and the sexually dimorphic genital field and IV-L, indicate that D. semiperforatus is a sister species of D. scapularis. Probably, there is a correlation between the evolution of sexual dimorphism (and hypothetically a differen- tiated reproductive behaviour) and the reduction in size of the male genital sceleton. The two species can be distinguished only on the base of the proportions of the chelicera (D. scapularis with short claw) and the male genital sceleton (D. scapularis with minute brachia proximalia). The presence of these two species in the Mediterranean area, but with a preference for habitats distinctly different in electrolyte concentrations, suggests that $D$. semiperforatus might have split off from a common stem species during the Miocene Mediterranean salinity crisis (Maldonado 1985).

Distribution: West mediterranean.

Diplodontus gracilirostris (Lundblad, 1942) nov. stat.

Discussion: This taxon described from Kenya as a subspecies of D. schaubi was later considered a synonym of the stem species (K.O. Viets 1964). However, it differs from all specimens of $D$. schaubi studied here in the dorsal muscle attachments associated with minute sclerite knobs, a very high L ratio basal segment/claw of 2.3, lower numbers of acetabula (about 100) and swimming hairs (III-L-5 4, IV-L-4 7, IV-L-5 8) and shorter leg segments (L IV-L-3 180, IV-L-5 260, IV-L-6 $260 \mu \mathrm{m})$. These important differences suggest that it should be regarded a separate species rather than a synonym of $D$. schaubi. Similar cheliceral proportions are found in D. scapularis, a species differing in a more stout palp and the tips of the subcuticular extensions of $\mathrm{Cx}-1 / 2$ directed medially, not bent in caudal direction.

Habitat: not defined.

Distribution: Kenya; only known from the locus typicus.

\section{Diplodontus chutteri (K.O. Viets, 1980)}

Figs 2 D; 3 D

Description: Female (male unknown): Idiosoma and gnathosoma rather small: idiosoma width 835-870 (original description, no data on length); measurements given here: L/W Cx-1+2 220/245, Cx-3+4 $290 / 315$, genital field 220/245, palpus total L 440, chelicera total L $345 \mu \mathrm{m}$ ); integument with disctinct sclerite dots marking the dorsal muscle attachments; medial margins of Cx-1+2 with subcutaneous sclerite borders at the posterior margin of the gnathosomal bay not extending medially; legs rather slender, bearing long, fine swimming hairs (numbers in parentheses) on segments II-L-5 (5), III-L-4 (8), III-L-5 (10), IV-L-4 (7), IV-L-5 (12); genital plates (Fig. 3 D) halfmoon-shaped, laterally equally rounded, without particularly extending posteromedial angles; maximum $\mathrm{W}$ in the 


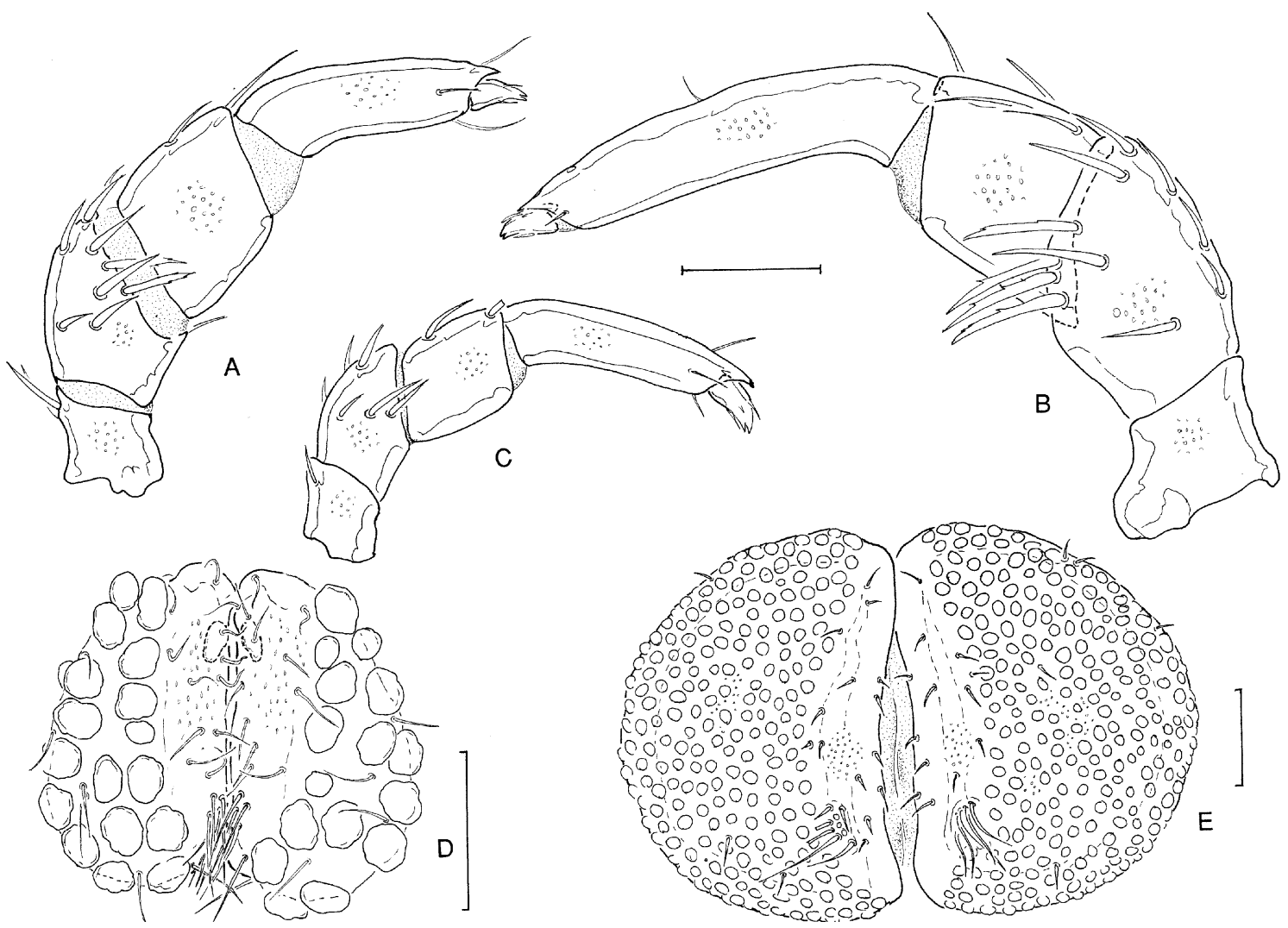

Fig. 3. A-C palps; D, E genital fields. A Diplodontus schaubi from Zaire, female (SMF 4623); B Diplodontus opimus paralectotype female (NMHU 1222); C, D Diplodontus chutteri holotype female (SMF 6502); E Diplodontus opimus lectotype male (NMHU 1226). Bars = 100 $\mu$ m.

centre of the genital field; a large strip of finely porous sclerite flanking the gonopore bearing about 35 setae; on each plate about 18 enlarged acetabula, with an irregular, not equally rounded surface; one further pair of acetabula lying in the smooth integument between the anterior part of the gonopore and the medial margins of the genital plates; gnathosoma with rather slender palps (Fig. 3 C, L/H P-2 1.8, P-4 4.9), P-2 with two medial setae; cheliceral claw (Fig. 2 D) short and relatively strong, slightly curved (basal segment/claw ratio 2.3).

Habitat: Rhithrobiont?

Discussion: $D$. chutteri differs from all other Diplodontus species not only in minute dimensions, low numbers of swimming hairs and acetabula, a slender genital field, short cheliceral claws and a slender palp, but in particular due to the presence of a pair of acetabula in the anterior area between gonopore and genital plates. These acetabula that escaped to the attention of
K.O.Viets, are obviously homologues to the Ac-1 found at this place in Hydryphantine mites, a taxonomic group that includes probably the outgroup of $\mathrm{Di}$ plodontus. Consequently, D. chutteri probably represents the sister group of all known Diplodontus species.

Distribution: South Africa; only known from the locus typicus.

\section{Diplodontus torrentium sp. nov.}

Figs 4; 5; 6 A; 8 A

Type series: Madagaskar, holotype male: MD 147b, Andapa (Antsiranana), right affl. R. Ambendrana downstream large cascade, $660 \mathrm{~m}$, riparian vegetation, Gerecke \& Goldschmidt 11.11.2001 MNHN (slide mounted in glycerine jelly); paratypes: same collecting site and date, 1 female MNHN (slide mounted in Hoyers fluid); 1 male (slide mounted in Hoyers fluid), 3 females ( 2 slide mounted in glycerine jelly, 1 undis- 


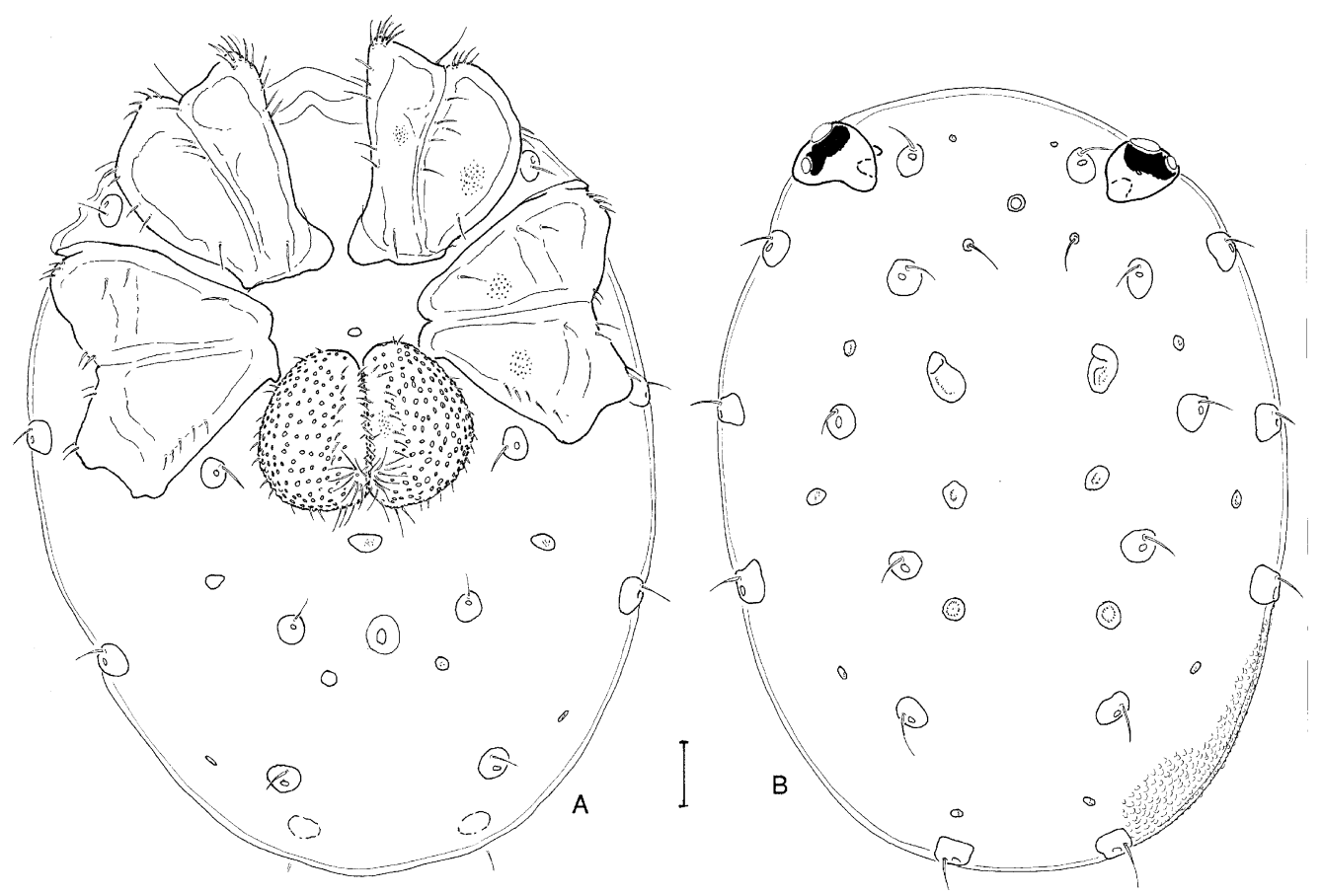

Fig. 4. Diplodontus torrentium, holotype male (MD 147b). A ventral view; B dorsal view. Bar $=100 \mu \mathrm{m}$.

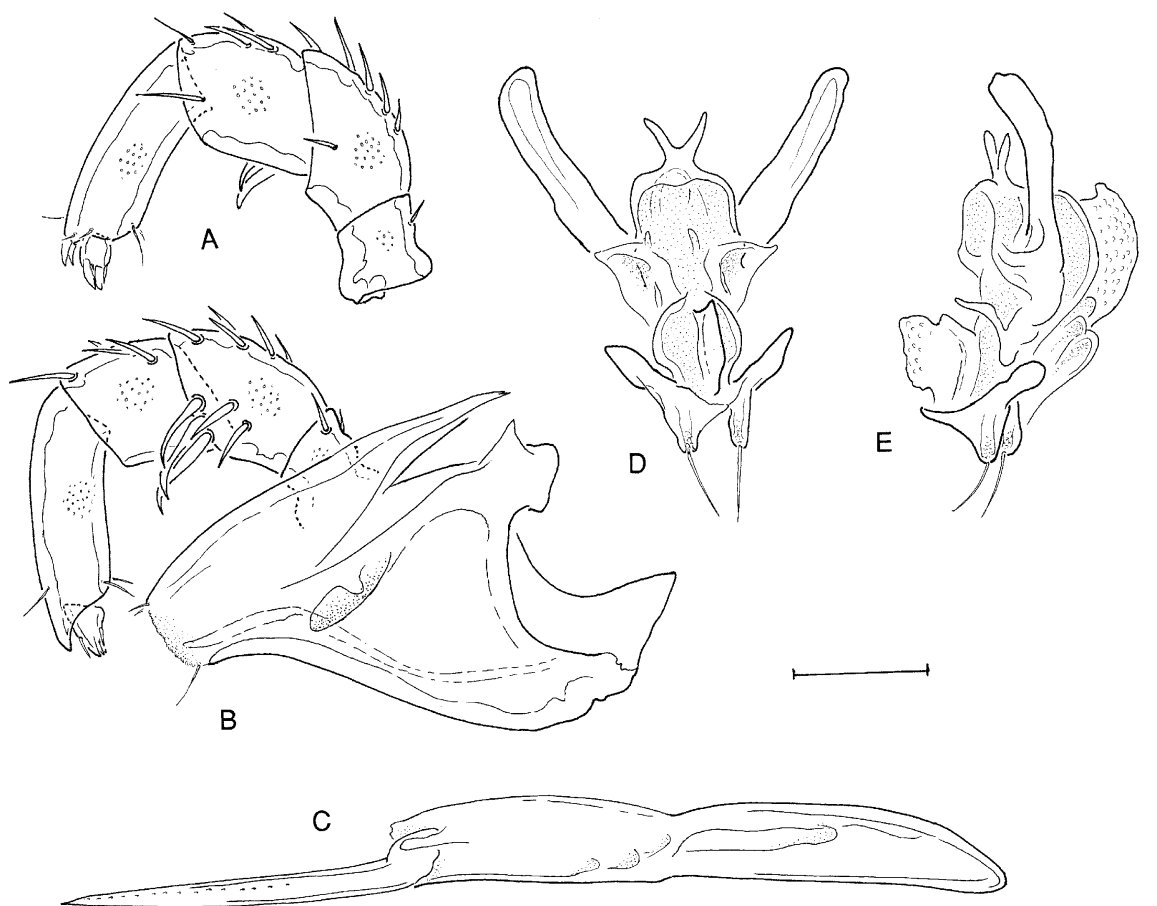

Fig. 5. Diplodontus torrentium, A-D paratype male, E holotype male (MD 147b). A palpus laterally; B gnathosoma and palpus medially; C chelicera; D genital sceleton anterior view, E genital sceleton lateral view. Bar $=100 \mu \mathrm{m}$. 
sected in Koenike's fluid), 1 deutonymph (slide mounted in glycerine jelly) in coll. Gerecke, Tübingen.

Further material examined: MD 032, Madiorano (Fianarantsoa), springs at left border of the stream crossing the railroad at $\mathrm{km} \mathrm{51.2,650} \mathrm{m,} \mathrm{Gerecke} \mathrm{\&}$ Goldschmidt 18.08.2001 1 deutonymph; MD 037, Andrambovato (Fianarantsoa), large cascade $3 \mathrm{~km}$ E from the village, $820 \mathrm{~m}$, Gerecke \& Goldschmidt 20.08.2001 1 deutonymph.

Diagnosis: Idiosoma with sclerotized muscle attachments arranged in the pattern plesiotypically found in Hydryphantoid mites; legs stout, covered by numerous strong setae, namely at distal segment margins, but completely devoid of swimming hairs; palp robust, with a ventrodistal group of strongly developed, apically curved setae on P-2; acetabula number > 250; genital sceleton L 270; chelicera basal segment/claw ratio $<1.65$.

Description: Both sexes (for a complete set of measurements see Table 1): Dorsalia 1 bean-shaped, the remaining muscle attachments developed as small, round sclerite knobs (Fig. 4 B); coxae (Fig. 4 A) with numerous fine setae, in particular concentration at the distal edge of $\mathrm{Cx}-1$; $\mathrm{Cx}-1+2$ each with a rounded, medially directed projection at the posterior margin of the gnathosomal bay, $\mathrm{Cx}-3+4$ with a minute, caudally directed apodeme at the medial edge; legs with high numbers of uniformly thick and stout setae, scattered over the dorsal and lateral surface of all segments 1-5, and arranged in dense rows at distal margins of these segments (see Fig. 8 A for setation of IV-L); genital field (Fig. 4 A) L/W 0.7-0.8, with halfmoon shaped genital flaps; medially with an acetabula-free, porose area flanked by two rows of fine hairs, and a further line of hairs surrounding the lateral border; mediocaudally a tuft of longer setae.

Gnathosoma (Fig. 5 B) with an equally S-shaped ventral margin, rostrum extending, with large, finely papillate lips surrounding the mouth opening; chelicera (Fig. 5 C) slender (L/H 10.4-11.3), with a strong, straight claw (L ratio basal segment/claw 1.5-1.6); palp setation as given in Figs $5 \mathrm{~A}, \mathrm{~B}$ : one pair of dorsal setae on $\mathrm{P}-1$, numerous such setae on $\mathrm{P}-2$ and -3 , one fine laterodistal setae each on P-2/-3, and a group of four to six conspicuous, large, apically curved setae mediodistally on $\mathrm{P}-2$.

Male: Idiosoma L 1350-1550 $\mu \mathrm{m}$; genital sceleton (Figs 5 D, E) L $270 \mu \mathrm{m}$, with strongly developed brachia proximalia and elevated anterior and posterior carenae.
Female: Idiosoma L $2000 \mu \mathrm{m}$; generally major in dimensions of idiosoma and appendages, but no sexual dimorphism in shape or proportions of legs and mouthparts. Genital field (Fig. 6 A) with higher number of genital setae, but mediocaudal setae shorter than in males.

Deutonymph: Differing from adults in minor dimensions and setae numbers, and in the shape of the genital field (with acetabula divided in two groups by a small, setae bearing sclerite bar as figured by Gerecke 1991 for D. semiperforatus); muscle attachment sclerites and mediodistal setae on P-2 well developed as in adults.

Discussion: The presence of similar, long and apically curved mediodistal setae on P-2 has been described for D. opimus, a pond dwelling species endemic in West Madagascar (see above). D. torrentium differs distinctly from it, and from all further known species of the genus, in the absence of swimming hairs on IIIV-L. This character appears combined with the presence of an increased number of short and thick setae, and with leg segments generally stouter in shape: range of $\mathrm{L} / \mathrm{H}$ ratio (with values for $D$. schaubi in parentheses) IV-L-2 1.4-1.6 (1.5-1.8); IV-L-3 2.1-2.4 (2.63.8); IV-L-4 3.3-3.7 (4.0-4.7); IV-L-5 3.5-4.2 (4.75.6); IV-L-6 3.4-4.4 (4.3-5.5). Sclerotized muscle attachments may be found in the dorsal and ventrocaudal integument of older specimens of other Diplodontus species as well (here reported for the first time for $D$. scapularis, D. semiperforatus and D. chutteri), but they have always the shape of round dots only, never extended and longish as in the anterodorsal idiosoma of D. torrentium.

If we hypothesize $D$. chutteri to be a representative of the outgroup of all remaining Diplodontus species, presence of swimming hairs and minute sclerotized muscle insertions are most probably plesiomorphic conditions in Diplodontines. In this scenario, D. torrentium represents an interesting evolutionary line adaptated to running waters by a transformation of leg shape and setation, and by an extension of idiosoma sclerotization (Mitchell 1958).

Habitat: Hygropetric habitats in rain forest streams. At site $147 \mathrm{~b}$ confined to the roots and submerged parts of terrestrial plants washed by waves below a cascade, but not found in fen and moss vegetation of the stream itself.

Distribution: Northeast Madagascar. The records in the Southern part of the rain forest belt (province Fianarantsoa) should be confirmed by collecting of adult specimens. 


\section{Diplodontus antsirananus sp. nov.}

Figs 6 B-E; 7; 8 B

Type series: Madagascar. Holotype male: MD 157, Joffreville (M. d'Ambre, Antsiranana), riparian springs at right affl. R. de Manques in Reserve Fontenay, $650 \mathrm{~m}$, Gerecke \& Goldschmidt, 18.11.2001 (slide mounted in glycerine jelly), MNHN. Paratypes: same collecting site and date, 1 male (slide mounted in Hoyer's fluid) coll. Gerecke, Tübingen; MD 154c Joffreville (M. d'Ambre, Antsiranana), R. de Manques in Reserve Fontenay, $550 \mathrm{~m}$, hygropetric, Gerecke \& Goldschmidt, 18.11.2001, 1 male (slide mounted in glycerine jelly), MNHN.

Diagnosis: Idiosoma with sclerotized muscle attachments arranged in the pattern plesiotypically found in Hydryphantoid mites; legs stout, covered by numerous strong setae, namely at distal segment margins, but completely devoid of swimming setae; palp robust, with a group of strongly developed ventrodistal setae on P-2; acetabula number $<150$; genital sceleton L $200 \mu \mathrm{m}$; chelicera basal segment/claw ratio $>1.80$.
Description: Male (female and deutonymph unknown): Idiosoma L 900-1100 $\mu \mathrm{m}$; sclerotization of muscle attachments, and shape and setation of coxae and genital field (Fig. 7), as described for D. torrentium; Legs with reduced numbers of medial and distal setae (e.g. Fig. 8 B, IV-L), proportions of IV-L segments (L/H): IV-L-1 1.36-1.42, IV-L-2 1.33-1.40, IVL-3 2.13-2.22, IV-L-4 3.29-3.38, IV-L-5 3.43-3.69; IVL-6 3.21-3.50; genital field (Fig. 7) with about 130 acetabula; genital skeleton (Fig. E) L 200-210 $\mu \mathrm{m}$, with brachia proximalia bent inwards; gnathosoma as described for D. torrentium; chelicera (Fig. 6 D) L/H 8.3-9.5, with a straight, rather robust claw, basal segment/claw 1.85-1.94; palpus as given in Figs 6 B, C, no setae found on P-1, P-2 with four conspicuous, enlarged mediodistal setae.

Discussion: From many points of view, D. antsirananus appears the «pocket version» of the preceeding species. D. torrentium and D. antsirananus agree (and differ from all so far known species of the genus) in the reinforced idiosoma sclerotization and absence of leg swimming hairs. However, differences are found not

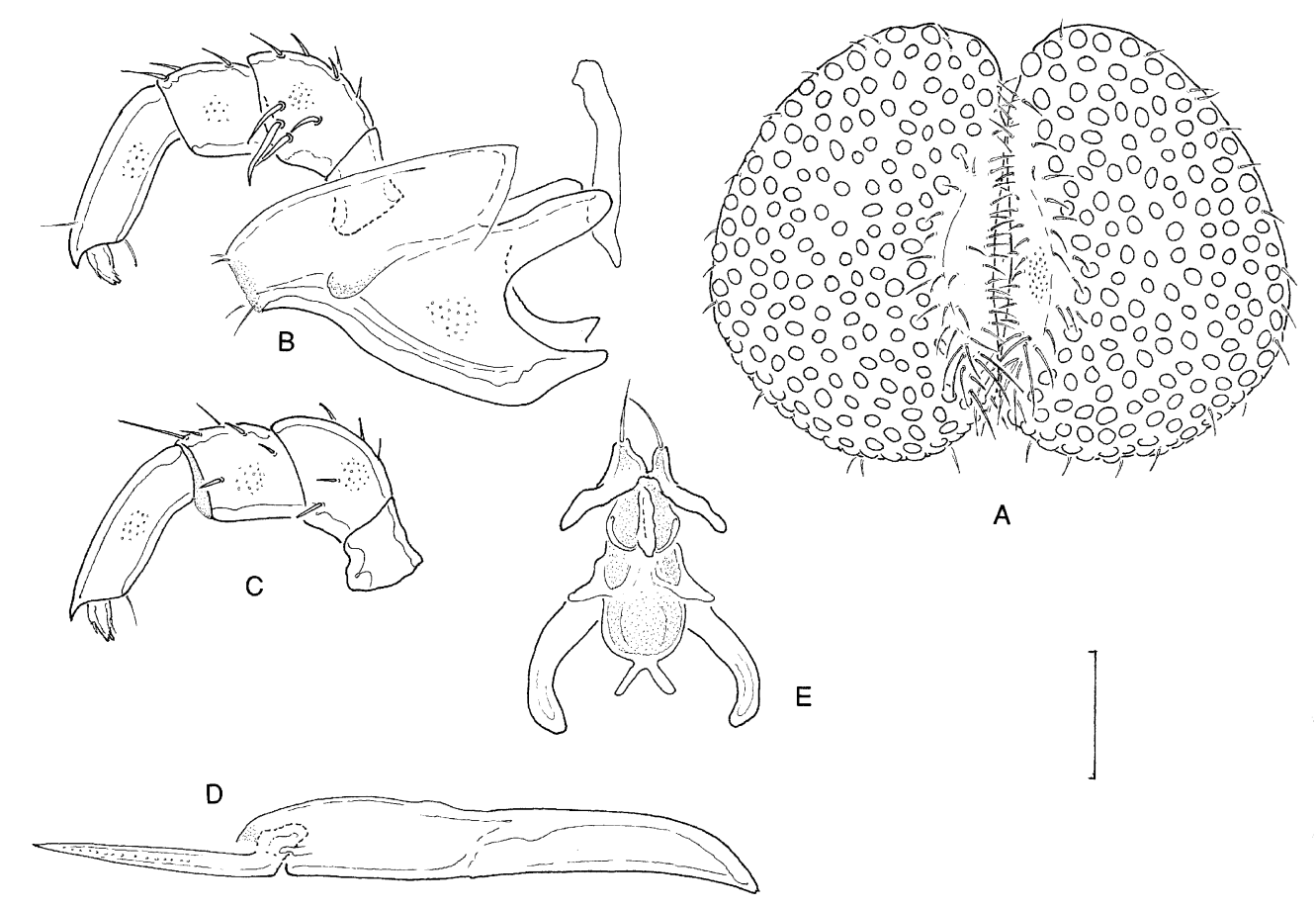

Fig. 6. A Diplodontus torrentium, paratypus female, genital field; B-E Diplodontus antsirananus, paratype male (MD 157). B gnathosoma and palpus medially; C palpus laterally; D chelicera; E genital skeleton anterior view. Bar $=100 \mu \mathrm{m}$. 


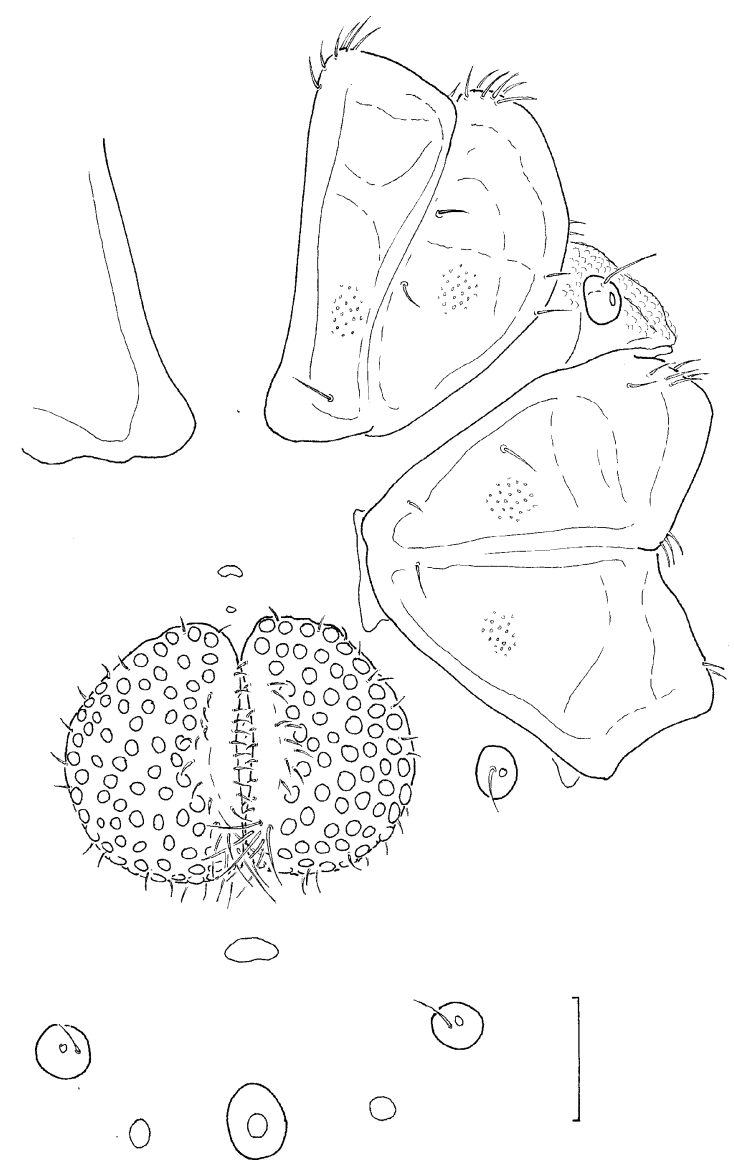

Fig. 7. Diplodontus antsirananus, holotype male, left coxal area and genital field. Bar $=100 \mu \mathrm{m}$.

only in idiosoma and appendage measurements, but $D$. antsirananus differs also in a reduced leg setation (for an example, compare Figs $8 \mathrm{~A}$ and $\mathrm{B}$ ), the brachia proximalia of the genital sceleton bent inwards, and a relatively short cheliceral claw (basal segment/claw ratio $>1.9$ ). There is much reason to suggest a common origin of these two species from a stem species that evolved during the past hundred Million years of isolation of Madagascar adaptations for torrential life unusual in this genus otherwhere on the world. On its turn, $D$. antsirananus has probably originated as a sister species of $D$. torrentium during the long term isolation of the Montagne d'Ambre in North Madagascar which has given origin to a high number of local endemics.
Habitat: Small running water bodies in rain forest: a weakly seeping helocrene spring at the foot of rocks bordering the stream, and hygropetric areas in the stream itself.

Distribution: North Madagascar; possibly endemic to the Montagne d'Ambre.

\section{Subfamily Diplodontinae: a new diagnosis}

Characters of the family Hydryphantidae; lateral eyes in capsules and these with well developed apodemes, median eye present and lying free in the integument; dorsalia and ventralia present or reduced; if swimming hairs present, these arranged in longitudinal lines on II-L-5, III-L-4/5 and IV-L-4/5, one to three additional swimmings hairs distally on IV-L-3; genital plates bearing numerous (from 30 to more than 600) acetabula, an additional pair may be present between the genital plates and the anterior part of the gonopore; numerous setae on genital plates, lined up along their medial margins or scattered between the acetabula, a characteristic group of longer setae at the posteromedial genital plate edge; cheliceral claw straight; P-2 mediodistally with one to six strong, sometimes curved setae.

Discussion: The detection of previously unknown character states in some species, such as muscle attachment scerites, legs with reduced swimming hairs, and a pair of acetabula in the membrane flanking the gonopore, has two effects: (1) relations to other hydryphantid subfamilies become more evident; (2) taxonomic separation against these groups becomes more difficult and the key published by Cook (1974) is no more compatible to all members of the genus.

In several clades of the Hydryphantidae, polyacetabulism has been reached convergently by multiplication of acetabula pairs 2 and 3 (for a discussion see Goldschmidt \& Gerecke 2003a). In most cases, these multiplied acetabula are arranged in the membranous integument laterally from the more or less reduced genital flaps and occasionally scattered setae surrounded by soft integument are the only remnants of former sclerite structures. The presence in $D$. chutteri of a pair of acetabula homologues to the hydryphantine acetabula 1 suggests that the diplodontine genital field (and probably also that of the members of the family Hydrodromidae) has evolved in a similar manner, with the only difference that the secondary acetabula remained included into the sclerified surface of genital plates. The general composition of the genital field of Diplodontus is rather similar to that in Eupatrella Walter, 1935 (Goldschmidt \& Gerecke 1993a), with multiplied, laterally arranged secondary acetabula (in 
Table 1. Diplodontus specimens from Madagascar, males; measurements (in $\mu \mathrm{m}$ ) and proportions.

\begin{tabular}{|c|c|c|c|c|c|c|c|}
\hline \multirow{2}{*}{$\begin{array}{l}\text { species } \\
\text { site }\end{array}$} & \multicolumn{3}{|c|}{ antsirananus } & \multicolumn{2}{|l|}{ torrentium } & \multirow{2}{*}{$\begin{array}{l}\text { opimus } \\
\text { NMHU } \\
1226\end{array}$} & \multirow{2}{*}{$\begin{array}{l}\text { schaubi } \\
\text { MNHN } \\
\text { B 101 }\end{array}$} \\
\hline & 157 & 157 & $154 \mathrm{c}$ & $147 \mathrm{~b}$ & $147 \mathrm{~b}$ & & \\
\hline Idiosoma L & 1100 & 1000 & 900 & 1350 & 1550 & & \\
\hline Idiosoma W & 850 & 800 & 700 & 1000 & 1200 & & \\
\hline$C x-1+2 L$ & 250 & 260 & 220 & 300 & 280 & 400 & 240 \\
\hline$C x-1+2 W$ & 315 & 300 & 300 & 400 & 395 & 650 & 410 \\
\hline$C x-3+4 L$ & 340 & 380 & 320 & 430 & 480 & 870 & 460 \\
\hline$C x-3+4 W$ & 280 & 300 & 250 & 360 & 340 & 780 & 450 \\
\hline Genital field $L$ & 200 & 200 & 180 & 270 & 280 & 400 & 280 \\
\hline Genital field W & 280 & 250 & 220 & 350 & 390 & 590 & 430 \\
\hline Genital field $L / W$ & 0.71 & 0.80 & 0.82 & 0.77 & 0.72 & 0.68 & 0.65 \\
\hline Ac number & 126 & 128 & 130 & 276 & 260 & 400 & 260 \\
\hline caudal genital hairs & 26 & 16 & 24 & 36 & 28 & 22 & 8 \\
\hline medial genital hairs & 24 & 20 & 20 & 26 & 28 & 26 & 16 \\
\hline genital hairs & 50 & 36 & 44 & 62 & 56 & 48 & 24 \\
\hline genital sceleton L & 210 & 200 & & 270 & 270 & 350 & 270 \\
\hline chelicera basal segment & 370 & 360 & 330 & 450 & 450 & & 300 \\
\hline chelicera claw & 200 & 190 & 170 & 300 & 280 & & 180 \\
\hline chelicera H & 60 & & 60 & 70 & 65 & & \\
\hline chelicera L & 570 & 550 & 500 & 750 & 730 & & 480 \\
\hline chelicera $\mathrm{L} / \mathrm{H}$ & 9.50 & & 8.33 & 10.71 & 11.23 & & \\
\hline chelicera bS/claw & 1.85 & 1.89 & 1.94 & 1.50 & 1.61 & & 1.67 \\
\hline gnathosoma ventral L & 260 & 260 & 250 & 290 & 320 & & \\
\hline gnathosoma dorsal L & & 290 & & 360 & & & \\
\hline P-1 L/H & $65 / 60$ & $55 / 55$ & & $65 / 70$ & $67 / 70$ & $90 / 90$ & $50 / 75$ \\
\hline P-1 ratio & 1.08 & 1.00 & & 0.93 & 0.96 & 1.00 & 0.67 \\
\hline P-2 L/H & $110 / 85$ & $110 / 85$ & & $130 / 105$ & $130 / 100$ & $175 / 140$ & $120 / 90$ \\
\hline P-2 ratio & 1.29 & 1.29 & & 1.24 & 1.30 & 1.25 & 1.33 \\
\hline P-3 L/H & $85 / 75$ & $75 / 75$ & & $90 / 85$ & $95 / 90$ & $115 / 115$ & $75 / 80$ \\
\hline P-3 ratio & 1.13 & 1.00 & & 1.06 & 1.06 & 1.00 & 0.94 \\
\hline P-4 L/H & $160 / 45$ & $155 / 45$ & & $200 / 54$ & $185 / 50$ & $225 / 65$ & $155 / 50$ \\
\hline P-4 ratio & 3.56 & 3.44 & & 3.70 & 3.70 & 3.46 & 3.10 \\
\hline P-5 L/H & $35 / 20$ & $35 / 20$ & & $42 / 20$ & $40 / 20$ & $45 / 20$ & $35 / 35$ \\
\hline P-5 ratio & 1.75 & 1.75 & & 2.10 & 2.00 & 2.25 & 1.75 \\
\hline palpus total L & 455 & 430 & & 527 & 517 & 650 & 435 \\
\hline P-2/P-4 L ratio & 0.69 & 0.71 & & 0.65 & 0.70 & 0.78 & 0.77 \\
\hline II-5 swimming hairs & 0 & 0 & 0 & 0 & 0 & 7 & 7 \\
\hline III-4/5 swimming hairs & 0 & 0 & 0 & 0 & 0 & $22 / 13$ & $9 / 11$ \\
\hline IV-3/4/5 swimming hairs & 0 & 0 & 0 & 0 & 0 & $0 / 22 / 29$ & $1 / 6 / 10$ \\
\hline IV-L-1 L/H & $170 / 120$ & & $150 / 110$ & $240 / 150$ & & $300 / 190$ & $190 / 110$ \\
\hline IV-L-1 ratio & 1.42 & & 1.36 & 1.60 & & 1.58 & 1.73 \\
\hline IV-L-2 L/H & $140 / 100$ & $140 / 100$ & $120 / 90$ & $170 / 120$ & & $270 / 180$ & $145 / 95$ \\
\hline IV-L-2 ratio & 1.40 & 1.40 & 1.33 & 1.42 & & 1.50 & 1.53 \\
\hline IV-L-3 L/H & $200 / 90$ & $200 / 90$ & $170 / 80$ & $260 / 110$ & & $430 / 150$ & $240 / 90$ \\
\hline IV-L-3 ratio & 2.22 & 2.22 & 2.13 & 2.36 & & 2.87 & 2.67 \\
\hline IV-L-4 L/H & $280 / 85$ & $270 / 80$ & $250 / 75$ & $360 / 100$ & & $620 / 140$ & $320 / 80$ \\
\hline IV-L-4 ratio & 3.29 & 3.38 & 3.33 & 3.60 & & 4.43 & 4.00 \\
\hline IV-L-5 L/H & $255 / 70$ & $240 / 70$ & $240 / 65$ & $340 / 90$ & & $680 / 120$ & $330 / 330$ \\
\hline IV-L-5 ratio & 3.64 & 3.43 & 3.69 & 3.78 & & 5.67 & 4.71 \\
\hline IV-L-6 L/H & $245 / 70$ & $235 / 70$ & $225 / 70$ & $320 / 80$ & & $530 / 85$ & $275 / 50$ \\
\hline IV-L-6 ratio & 3.50 & 3.36 & 3.21 & 4.00 & & 6.24 & 5.50 \\
\hline
\end{tabular}


Table 2. Diplodontus specimens from Madagascar, females; measurements (in $\mu \mathrm{m}$ ) and proportions.

\begin{tabular}{|c|c|c|c|c|c|c|c|c|c|}
\hline \multirow{2}{*}{$\begin{array}{l}\text { species } \\
\text { site }\end{array}$} & \multicolumn{2}{|l|}{ torrentium } & \multicolumn{4}{|l|}{ opimus } & \multicolumn{3}{|l|}{ schaubi } \\
\hline & $147 \mathrm{~b}$ & $147 \mathrm{~b}$ & $\begin{array}{l}\text { NMHU } \\
1222 \\
\end{array}$ & $\begin{array}{l}\text { NMHU } \\
1222 / 2\end{array}$ & $\begin{array}{l}\text { NMHU } \\
1223 \\
\end{array}$ & $\begin{array}{l}\text { NMHU } \\
1225 \\
\end{array}$ & $\begin{array}{l}\text { MNHN } \\
\text { B 151 }\end{array}$ & $\begin{array}{l}\text { MNHN } \\
\text { E } 14 \mathrm{M}\end{array}$ & $\begin{array}{l}\text { MNHN } \\
\text { E } 14 \mathrm{M}\end{array}$ \\
\hline Idiosoma L & 2000 & & & & & & & & \\
\hline Idiosoma W & 1600 & & & & & & & & \\
\hline$C x-1+2 L$ & 320 & & & & & 460 & 230 & 250 & 270 \\
\hline$C x-1+2 W$ & 440 & & & & & 720 & 430 & 430 & 430 \\
\hline$C x-3+4 L$ & 500 & & & & & 800 & 500 & 430 & 480 \\
\hline$C x-3+4 W$ & 420 & & & & & 860 & 480 & 410 & 430 \\
\hline Genital field $L$ & 290 & & & & & 400 & 290 & 230 & \\
\hline Genital field W & 410 & & & & & 650 & 490 & 360 & \\
\hline Genital field $L W$ & 0.71 & & & & & 0.62 & 0.59 & 0.64 & \\
\hline Ac number & 308 & & & & & 500 & 620 & 310 & \\
\hline caudal genital hairs & 52 & & & & & 20 & 26 & 14 & \\
\hline medial genital hairs & 40 & & & & & 24 & 36 & 26 & \\
\hline genital hairs & 92 & & & & & 44 & 62 & 40 & \\
\hline chelicera basal segment & 510 & & 640 & 600 & 640 & & 440 & 370 & 410 \\
\hline chelicera claw & 320 & & 300 & 300 & 300 & & 270 & 200 & 220 \\
\hline chelicera H & 80 & & 120 & 120 & 130 & & 90 & 80 & 60 \\
\hline chelicera L & 830 & & 940 & 900 & 940 & & 710 & 570 & 630 \\
\hline chelicera $L / H$ & 10.38 & & 7.83 & 7.50 & 7.23 & & 7.89 & 7.13 & 10.50 \\
\hline chelicera bS/claw & 1.59 & & 2.13 & 2.00 & 2.13 & [1.93] & 1.63 & 1.85 & 1.86 \\
\hline gnathosoma ventral $L$ & 360 & & & & & & 290 & 225 & 310 \\
\hline gnathosoma dorsal L & 400 & & & & & & 360 & 300 & 315 \\
\hline P-1 LH & $75 / 85$ & & $90 / 120$ & $100 / 110$ & & & $60 / 90$ & $60 / 80$ & $70 / 90$ \\
\hline P-1 ratio & 0.88 & & 0.75 & 0.91 & & & 0.67 & 0.75 & 0.78 \\
\hline P-2 L/H & $150 / 105$ & & $190 / 160$ & $190 / 180$ & & & $130 / 105$ & $115 / 95$ & $125 / 100$ \\
\hline P-2 ratio & 1.43 & & 1.19 & 1.06 & & & 1.24 & 1.21 & 1.25 \\
\hline P-3 L/H & $100 / 105$ & & $140 / 130$ & $130 / 140$ & & & $100 / 100$ & $90 / 90$ & $85 / 90$ \\
\hline P-3 ratio & 0.95 & & 1.08 & 0.93 & & & 1.00 & 1.00 & 0.94 \\
\hline P-4 L/H & $210 / 60$ & & $310 / 70$ & $320 / 75$ & & & $190 / 60$ & $160 / 55$ & $180 / 60$ \\
\hline P-4 ratio & 3.50 & & 4.43 & 4.27 & & & 3.17 & 2.91 & 3.00 \\
\hline P-5 L/H & $42 / 20$ & & $40 / 20$ & $40 / 20$ & & & $40 / 20$ & $30 / 30$ & $35 / 35$ \\
\hline P-5 ratio & 2.10 & & 2.00 & 2.00 & & & 2.00 & 1.50 & 1.75 \\
\hline paipus total L & 577 & & 770 & 780 & & & 520 & 455 & 495 \\
\hline$P-2 / P-4 L$ ratio & 0.71 & & 0.61 & 0.59 & & & 0.68 & 0.72 & 0.69 \\
\hline II-5 swimming hairs & 0 & 0 & & & & 11 & 10 & 10 & 8 \\
\hline III-4/5 swimming hairs & 0 & 0 & & & & $27 / 35$ & $11 / 18$ & $5 / 15$ & $12 / 14$ \\
\hline IV-3/4/5 swimming hairs & 0 & 0 & & & & $2 / 35 / 40$ & $2 / 13 / 18$ & $3 / 12 / 10$ & $1 / 18 / 15$ \\
\hline IV-L-1 L/H & $228 / 150$ & $290 / 180$ & & & & $310 / 200$ & $185 / 130$ & & \\
\hline IV-L-1 ratio & 1.52 & 1.61 & & & & 1.55 & 1.42 & & \\
\hline IV-L-2 L/H & $180 / 120$ & $220 / 140$ & & & & $290 / 190$ & $180 / 110$ & $160 / 90$ & \\
\hline IV-L-2 ratio & 1.50 & 1.57 & & & & 1.53 & 1.64 & 1.78 & \\
\hline IV-L-3 L/H & $285 / 130$ & $320 / 140$ & & & & $480 / 170$ & $320 / 105$ & $280 / 75$ & \\
\hline IV-L-3 ratio & 2.19 & 2.29 & & & & 2.82 & 3.05 & 3.73 & \\
\hline IV-L-4 L/H & $400 / 110$ & $440 / 130$ & & & & $700 / 160$ & $420 / 90$ & $370 / 80$ & \\
\hline IV-L-4 ratio & 3.64 & 3.38 & & & & 4.38 & 4.67 & 4.63 & \\
\hline IV-L-5 L/H & $370 / 90$ & $390 / 110$ & & & & $730 / 130$ & $420 / 75$ & $370 / 70$ & \\
\hline IV-L-5 ratio & 4.11 & 3.55 & & & & 5.62 & 5.60 & 5.29 & \\
\hline IV-L-6 L/H & $330 / 75$ & $340 / 100$ & & & & $500 / 90$ & $320 / 60$ & $260 / 60$ & \\
\hline IV-L-6 ratio & 4.40 & 3.40 & & & & 5.56 & 5.33 & 4.33 & \\
\hline
\end{tabular}




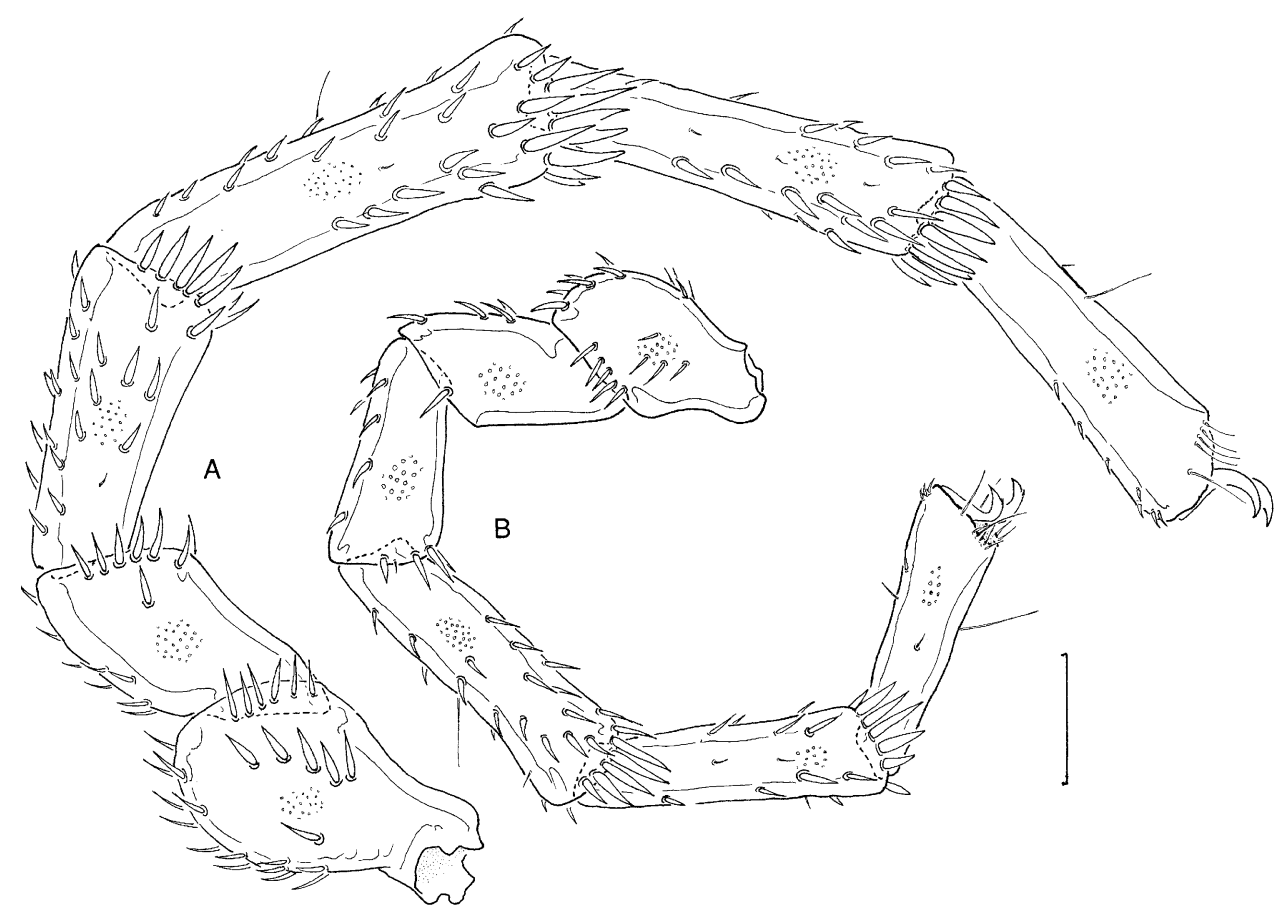

Fig. 8. A, B: IV-L. A Diplodontus torrentium, holotype male (MD 147b); B Diplodontus antsirananus, paratype male (MD 154). Bar $=100 \mu \mathrm{m}$.

Eupatrella on stalks in the soft integument) and numerous setae flanking the gonopore in two groups, with shorter anterior, and longer posterior setae (in Eupatrella distributed to two pairs of platelets). Eupatrellinae and Diplodontinae are furthermore similar in the presence of small, but distinct muscle insertion sclerites, and simple leg claws - both probably plesiomorphic character states. Investigations on larval morphology and life cycles of selected hydryphantine genera would be the best way to bring further light in their taxonomical interrelations.

\section{Acknowledgements}

The author's field work in Madagascar in 2001 that initiated this investigation was made possible by generous sponsoring by D.R. Cook (Paradise Valley, USA). Tom Goldschmidt was a reliable companion both during the journey and the following sorting work. Felix Rakotondraparany (Antananarivo) was our project partner and helped to resolve numerous problems. The taxonomic study found financial support by grants of the MNHN Paris (Colparsyst) and SMNH Stockholm (HighLat), with kind assistance by Marc Judson and Torbjørn Kronestedt, respectively. Peter Jäger (SMF) and Jason Dunlop (NMHU) helped with loan of type material, Ignacio Ribera (Madrid), Pedro Aguila and Carles Hernando (Barcelona), and Andres Millan (Murcia) made available a valuable water mite collection from Morocco. Arne Panesar (Freiburg) made available a specimen of $D$. silvestrii from his collections in India.

\section{References}

Cook D.R. 1967. - Water mites from India. Mem. Amer. Ent. Inst., 9, III+1-411.

Cook D.R. 1974. - Water mite genera and subgenera. Mem. Amer. Ent. Inst., 21, VII + 1-860.

Gerecke R. 1991. - Taxonomische, faunistische und ökologische Untersuchungen an Wassermilben (Acari, Actinedida) aus Sizilien unter Berücksichtigung anderer aquatischer Invertebraten. Lauterbornia, 7, 1-304.

Gerecke R. 1996. - Untersuchungen über Wassermilben der Familie Hydryphantidae (Acari, Actinedida) in der Westpalaearktis, II. Die Wassermilben der Familie Hydryphantidae Piersig, 1896 in den Mittelmeerländern. Arch. Hydrobiol. Suppl., 77 (3/4), 337-513.

Gerecke R. in press. - The Water mites of Madagascar (Acari: Hydrachnidia) - a revised list completed by original material conserved at the Muséum National d'Histoire Naturelle Paris - Zoosystema. 
Goldschmidt T. \& Gerecke R. 2003. - Zur Kenntnis der Wassermilbenfauna (Acari, Hydrachnidia) in Fließgewässern und Quellen auf Madagaskar. DGL Tagungsbericht 2002: 755-760.

Goldschmidt T. \& Gerecke R. 2003a. - Studies on Hydryphantid water mites (Acari: Actinedida: Hydrachnidia) from Central and South America. Pages 83-150 in An Acarological Tribute to David R. Cook - From Yankee Springs to Wheeny Creek. Smith I.M. (ed.). Indira Publ., West Bloomfield.

Jin Daochao 1995. - Hydrachnellae - Morphology, Systematics. A primary study of chinese fauna. Guizhou science and technology publishing house: $356 \mathrm{pp}$. (in chinese).

Koenike F. 1893. - Die von Herrn Dr. F. Stuhlmann in Ostafrika gesammelten Hydrachniden des Hamburger naturhistorischen $\mathrm{Mu}$ seums. Jbch. Hamb. Wiss. Anst., 10 (19), 1-55

Koenike F. 1898. - Hydrachniden-Fauna von Madagaskar und Nossi-Bé. Abh. Senckenberg. naturf. Ges. Frankfurt/M., 21 (2), 295-435.

Lundblad O. 1942. - Afrikanische Hydracarinen. Ent. Tidskr., 63 (3-4), 155-209.
Lundblad O. 1947. - Zur Kenntnis australischer Wassermilben. Ark. Zool.n 40, A (2), 1-82.

Mitchell R.D. 1958. - The evolution of exoskeletons and mite phylogeny. Int. Congr. Entom. Proc., 1, 863-865.

Moreno Alcaraz J.L., Gerecke R. \& Tuzovskij P. submitted. - The larval stage and life cycle of Diplodontus scapularis Dugés, 1834 and D. semiperforatus Walter, 1925 (Acari: Hydrachnidia), with remarks on their habitat preference and distribution in the South West palaearctic region.

Viets K.O. 1964. - Neufunde und Taxonomie afrikanischer Hydrachnellae (Acari). Acarologia, 6 (1), 129-162.

Viets K.O. 1973. - Wassermilben (Hydrachnellae, Acari) aus dem Gebiet des Kivu-Sees, Zaire (Kongo). Acarologia, 15 (2), 324-336.

Viets K.O. 1980. - Über Diplodontus-Arten (Hydrachnellae, Acari). Mitt. Zool. Mus. Berlin, 56 (1), 99-101.

Viets K. 1911. - Neue afrikanische Hydracarinen. Zool. Anz, 37 (6-7), 153-157. 